\title{
Histochemical and Organolyptic Analysis of Major Aroma Compound (2-acetyl-1-pyrroline) in Kalanamak Rice Landraces and Some Basmati Rice Varieties
}

\section{Anita Kumari*, Anil Kumar and Anil Kumar Gaur}

Molecular Biology and Genetic Engineering, Collage of Basic Sciences and Humanities, G.B. Pant University of Agriculture and Technology, Pantnagar, India

*Corresponding author: Anita Kumari, Molecular Biology and Genetic Engineering Collage of Basic Sciences and Humanities, G.B. Pant University of Agriculture and Technology, Pantnagar (Uttrakhand), India, Tel: 8449327911; Email: anitaani91@gmail.com

\section{Abstract}

In the present paper, the histochemical analysis was carried out to localize the presence of aroma compound i.e 2-acetyl1-pyrroline in the rice caryopsis of the kalanamak rice landraces. For the localization of 2-AP, reagent 2, 4-Dinitrophenyl hydrazine was used. Presence of the aroma was confirmed by organolyptic analysis of the Kalanamak rice accessions, Type-3, Pusa Basmati-1 and PantDhan-18.The sensory test appeared to be a simple and reliable method for rapid identification of aromatic rice. This study may help in better understanding the biology of rice grain and improvement of rice quality.

\section{Introduction}

Rice (Oryza sativa L.) is the staple food for more than two billion people in Asia. The cultivation of high-quality rice has significantly increased in recent years, and consequently, the aromatic rice cultivars grown in Asian countries are attracting attention [1]. Small variations in sensory properties can change the perception of the consumers, whether highly desired by or unacceptable to consumers [2]. Consequently, aroma and flavor have been rated as the major criteria for preference among consumers [3]. To increase the production of aromatic rice and satisfy the diversification of the demand from current rice consumers worldwide, it is necessary to develop the suitable breeding methods of aromatic rice.

\section{Materials and Methods}

The evaluation of rice aroma is not easy, and classical smelling or chewing methods are not supposed to be totally reliable because of their subjective nature [4]. For the sensory evaluation, seeds of all the genotypes of Kalanamak, Type- 3 and Pusa basmati-1 and non-scented Pantdhan-18 were collected from Norman E. Boralog Crop Research Centre of GBPUA \& T, Pantnagar (U.K.), India. All the genotypes of Kalanamak, Pantdhan-18, Type- 3 and Pusa Basmati-1 were manually dehusked. For the test using seeds, 10 seeds of each genotype were taken in Stoppard test tubes. About $10 \mathrm{ml} 1.7 \% \mathrm{KOH}$ solution was added to each Stoppard test tube and left at room temperature for $30 \mathrm{~min}$. After 30 minutes, each 


\section{Cell \& Cellular Life Sciences Journal}

Stoppard test tube was opened and the degree of aroma was evaluated by sniffing and was scored on the 1-4 scale with 1, 2, 3 and 4 corresponding to the absence of aroma, slight aroma, moderate aroma and strong aroma. The score for each sample was recorded by a panel of 5 experts according. All measurements were recorded in triplicates and these were expressed as mean \pm SE.

For histochemical studies, Seeds of all the varieties were soaked overnight to soften the seed-coat and were manually dehusked and hand-cut transverse sections were obtained using a razor blade. Theses thin sections were transferred through $60 \%$ alcohol grade. Afterward, Sections were transferred to 2, 4-dinitrophenyl hydrazine reagent in a beaker and incubated in hot air oven at $60^{\circ} \mathrm{C}$ for 30 min. Later sections were mounted by Canada balsam and observed under bright field microscope [5].

\section{Results and Discussion}

The presence or absence of aroma in the rice seeds was assessed for 70 Kalanamak rice accessions, Type-3, Pusa Basmati-1 and PantDhan-18 from Uttrakhand region. Table 1 lists the aroma responses of the rice cultivars. The result showed that most of the Kalanamak Genotypes were found give moderate to the slight aroma. Out of 70 Genotypes, 4 genotypes had the strong aroma, 38 genotypes had the slight aroma and 26 genotypes had the moderate aroma.

\begin{tabular}{|c|c|c|c|}
\hline Genotype & Accession No & Weight/ Seeds (gm) & Aroma \\
\hline Pant Dhan 18 & - & 0.21 & 1 \\
\hline Pusa Bas.-1 & - & 0.17 & 3 \\
\hline Type-3 & - & 0.16 & 2 \\
\hline Kalanamak 1 & 3089-P & 0.10 & 2 \\
\hline Kalanamak 2 & 3089-SN & 0.10 & 2 \\
\hline Kalanamak 3 & 3144-SN & 0.11 & 2 \\
\hline Kalanamak 4 & 3114-1-P & 0.09 & 2 \\
\hline Kalanamak 5 & $3114-1-S N$ & 0.11 & 3 \\
\hline Kalanamak 6 & $3114-2-\mathrm{P}$ & 0.12 & 2 \\
\hline Kalanamak 7 & $3117-\mathrm{P}$ & 0.12 & 4 \\
\hline Kalanamak 8 & 3117-SN & 0.11 & 2 \\
\hline Kalanamak 9 & $3119-\mathrm{P}$ & 0.12 & 3 \\
\hline Kalanamak 10 & 3119-SN & 0.10 & 3 \\
\hline Kalanamak 11 & $3119-1-S N$ & 0.12 & 2 \\
\hline Kalanamak 12 & $3119-2-\mathrm{P}$ & 0.12 & 2 \\
\hline Kalanamak 13 & $3119-2-\mathrm{SN}$ & 0.11 & 4 \\
\hline Kalanamak 14 & $3120-\mathrm{P}$ & 0.12 & 3 \\
\hline Kalanamak 15 & $3120-\mathrm{SN}$ & 0.13 & 2 \\
\hline Kalanamak 16 & $3120-1-\mathrm{P}$ & 0.12 & 2 \\
\hline Kalanamak 17 & $3120-1-\mathrm{SN}$ & 0.13 & 3 \\
\hline Kalanamak 18 & $3120-2-\mathrm{P}$ & 0.12 & 3 \\
\hline Kalanamak 19 & 3120-2-SN & 0.12 & 3 \\
\hline Kalanamak 20 & $3121-\mathrm{P}$ & 0.10 & 3 \\
\hline Kalanamak 21 & $3121-\mathrm{SN}$ & 0.11 & 2 \\
\hline Kalanamak 22 & 3121-1-SN & 0.16 & 2 \\
\hline Kalanamak 23 & 3122-P & 0.17 & 4 \\
\hline Kalanamak 24 & $3122-\mathrm{SN}$ & 0.18 & 2 \\
\hline Kalanamak 25 & 3124-P & 0.17 & 2 \\
\hline Kalanamak 26 & $3124-\mathrm{SN}$ & 0.18 & 2 \\
\hline Kalanamak 27 & $3125-\mathrm{SN}$ & 0.17 & 3 \\
\hline Kalanamak 28 & $3126-P$ & 0.17 & 2 \\
\hline Kalanamak 29 & $3126-\mathrm{SN}$ & 0.16 & 2 \\
\hline Kalanamak 30 & 3128-P & 0.20 & 3 \\
\hline
\end{tabular}




\section{Cell \& Cellular Life Sciences Journal}

\begin{tabular}{|c|c|c|c|}
\hline Kalanamak 31 & 3128-SN & 0.14 & 3 \\
\hline Kalanamak 32 & 3129-P & 0.12 & 2 \\
\hline Kalanamak 33 & 3129-SN & 0.14 & 2 \\
\hline Kalanamak 34 & $3130-\mathrm{P}$ & 0.13 & 3 \\
\hline Kalanamak 35 & $3130-\mathrm{SN}-\mathrm{CH}$ & 0.19 & 3 \\
\hline Kalanamak 36 & 3131-SN-CH & 0.17 & 2 \\
\hline Kalanamak 37 & 3131-SN & 0.11 & 2 \\
\hline Kalanamak 38 & 3131-P & 0.10 & 3 \\
\hline Kalanamak 39 & $3131-2-\mathrm{P}$ & 0.12 & 3 \\
\hline Kalanamak 40 & 3131-2-SN & 0.11 & 1 \\
\hline Kalanamak 41 & $3212-\mathrm{P}$ & 0.13 & 3 \\
\hline Kalanamak 42 & 3212-CH-SN & 0.10 & 2 \\
\hline Kalanamak 43 & 3213-SN & 0.11 & 3 \\
\hline Kalanamak 44 & 3214-N & 0.10 & 3 \\
\hline Kalanamak 45 & 3214-SN & 0.13 & 2 \\
\hline Kalanamak 46 & $3215-\mathrm{P}$ & 0.16 & 2 \\
\hline Kalanamak 47 & $3215-\mathrm{SN}$ & 0.16 & 3 \\
\hline Kalanamak 48 & 3215-1-P & 0.14 & 3 \\
\hline Kalanamak 49 & $3216-\mathrm{P}$ & 0.15 & 3 \\
\hline Kalanamak 51 & $3216-\mathrm{SN}$ & 0.14 & 2 \\
\hline Kalanamak 52 & 3216-1-P & 0.17 & 3 \\
\hline Kalanamak 53 & 3219-P & 0.15 & 2 \\
\hline Kalanamak 54 & 3219-SN & 0.17 & 2 \\
\hline Kalanamak 55 & $3221-\mathrm{SN}$ & 0.15 & 2 \\
\hline Kalanamak 56 & $3222-\mathrm{P}$ & 0.17 & 2 \\
\hline Kalanamak 58 & 3224-P & 0.13 & 2 \\
\hline Kalanamak 59 & 3229-SN & 0.15 & 2 \\
\hline Kalanamak 60 & 3256-P & 0.16 & 2 \\
\hline Kalanamak 61 & 3256-CH-SN & 0.14 & 2 \\
\hline Kalanamak 63 & $3257-\mathrm{P}$ & 0.12 & 2 \\
\hline Kalanamak 64 & 3257-CH-P & 0.12 & 3 \\
\hline Kalanamak 65 & $3253-\mathrm{SN}$ & 0.13 & 3 \\
\hline Kalanamak 66 & $3266-\mathrm{P}$ & 0.12 & 2 \\
\hline Kalanamak 67 & 3266-1-P & 0.11 & 2 \\
\hline Kalanamak 68 & $3266-\mathrm{SN}$ & 0.11 & 4 \\
\hline Kalanamak 69 & 3266-4-P & 0.13 & 2 \\
\hline Kalanamak 70 & 3278-P & 0.13 & 3 \\
\hline \multicolumn{4}{|c|}{ Mean - 2.485 } \\
\hline \multicolumn{4}{|c|}{ Range - 1-4 } \\
\hline \multicolumn{4}{|c|}{ STD - 0.651} \\
\hline
\end{tabular}

Table 1: Organolyptic analysis of Kalanamak rice accessions, Type-3, Pusa Basmati-1 and PantDhan-18.

From the earlier studies, it was concluded the 2-AP was present in the aleurone layer than the endosperm [6,7]. Histochemical studies revealed that aromatic compound i.e. 2-acetyl-1-pyrroline was present in the aleurone layer. 2, 4- dinitrophenyl hydrazine reacts with methyl ketones to give an orange-red color. 


\section{Cell \& Cellular Life Sciences Journal}

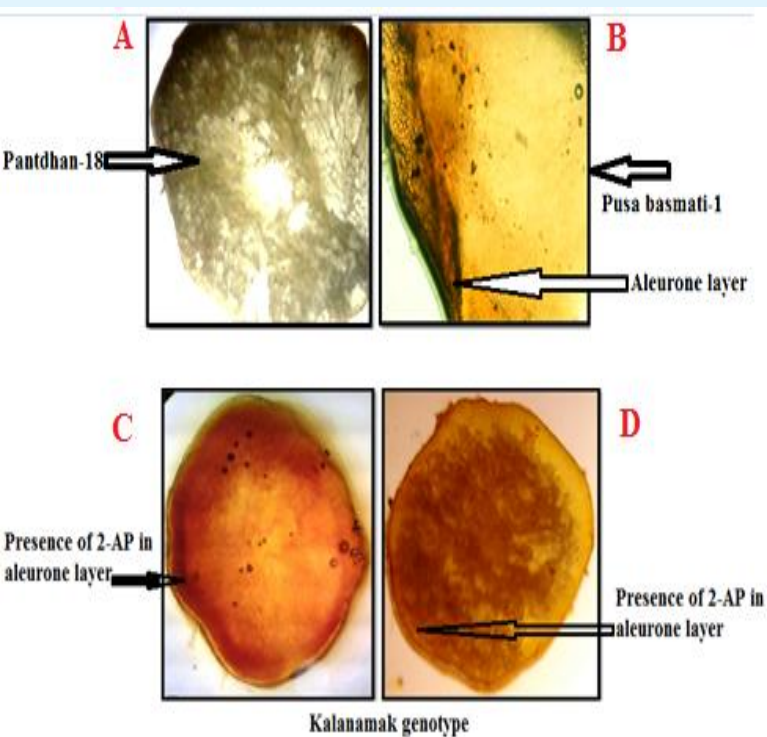

Figure 1: Histochemical analysis of rice genotype: A) Pantdhan-18 showing no reaction with 2, 4-Dinitrophenyl hydrazine in the aleurone layer. B) Pusa Basmati-1: showing a reaction with 2, 4-Dinitrophenyl hydrazine in the aleurone layer. C and D) Kalanamak 7 \& 13 accessions showing reaction with 2,4-Dinitrophenyl hydrazine in the aleurone layer.

2-acetyl-1-pyiroline + 2,4-dinitrophenylhydrazine $\rightarrow$ 2-acetyl-phenyl hydrazone (orange-red colouri')

Organoleptic test with consumer preferences of different rice accessions provides information for improvement of valuable grain quality traits. So it is important to identify the aromatic substances determining the aroma in rice. In addition, further studies should be carried out to confirm the precursors and pathways of 2-AP formation in aromatic rice cultivars to elucidate the nature and expression of the aroma trait in rice.

\section{Acknowledgements}

We are thankful to the Department of Biotechnology, Government of India, for funding this work under the Program Mode Support in Agricultural Biotechnology Initiative.

\section{References}

1. Hien NL, Yoshihashi T, Sarhadi WA, Thanh VC, Oikawa Y, et al. (2006) Evaluation of Aroma in Rice (Oryza sativa L.) using KOH Method, Molecular Markers and Measurement of 2-Acetyl-1-Pyrroline Concentration. Jpn J Trop Agr 50(4): 190-198.

2. Yau NJN, Liu TT (1999) Instrumental and sensory analysis of volatile aroma of cooked rice. J Sens Stud 14: 209-233.

3. Del Mundo AM, Juliano BO (1981) Consumer preference and properties of raw and cooked milled rice. J Texture Stud 12: 107-120.

4. Garris AJ, Tai TH, Coburn J, Kresovich S, McCouch S (2005) Genetic Structure and Diversity in Oryza sativa L. Genetics 169(3): 1631-1638.

5. Nadaf AB, Krishnan S, Wakte KV (2006) Histochemical and biochemical analysis of major aroma compound (2-acetyl-1-pyrroline) in basmati and other scented rice (Oryza sativa L). Current Science 91(11): 1533-1536.

6. Buttery RG, Ling LC, Juliano BO, Turnbaugh JC (1983) Cooked rice aroma and 2-acetyl-1-pyrroline. J Agric Food Chem 31(4): 823-826.

7. Buttery RG, Juliano BO, Ling LC (1983) Identification of rice aroma compound 2-acetyl-1-pyrroline in pandan leaves. Chem Ind 478. 